ACTA VET. BRNO, 55, 1986:333-342

\title{
TYPING OF STAPHYLOCOCCUS AUREUS, STAPHYLOCOCCUS INTERMEDIUS AND COAGULASE-NEGATIVE STAPHYLOCOCCI BY MEANS OF STAPHYLOCOCCAL BACTERIOCINS
}

\author{
B. SKALKA \\ Department of Epizootiology and Microbiology, University of Veterinary \\ Science, 61242 Brno
}

Received October 31, 1985

Abstract

S k a l ka B . : Typing of Staphylococcus aureus, Staphylococcus intermedius and Coagulase-negative Staphylococci by means of Staphylococcal Bacteriocins. Acta vet. Brno, 55, 1986: 333-342.

Sensitivity to staphylococcal bacteriocins was examined in 1,314 staphylococcal strains, isolated from man and animals. The strains under study did not produce bacteriocins. S. aureus UTO0O2, S. intermedius $O P-42, S$. intermedius $O P-12$, and $S$. epidermidis $K 14$ were used as producers of bacteriocins. The set of examined strains was represented by $730 \mathrm{~S}$. aureus biovar C, $111 \mathrm{~S}$. aureus biovar A, $34 \mathrm{~S}$. aureus biovar B, $5 \mathrm{~S}$. aureus bicvar D, $224 \mathrm{~S}$. intermedius and 210 coagulase-negative staphylococci. The deferred method was employed for the assays. The strains of biovar $C$ were characterized by sensitivity to bacteriocins of all four producers, whilst S. aureus strains of other biovars were susceptible to bacteriocins UTO002 and K14, but resistant towards OP-42 and $\mathrm{OP}-12$. S. intermedius strains were characterized by resistance to UT0002 bacteriocin but $53 \%$ of them were sensitive to bacteriocins Kl4, OP-42 and OP-12. 31 \% of $\mathrm{S}$. intermedius strains were sensitive exclusively to $K 14$ and $8 \%$ strains were found quite resistant. A similar complete resistance was shown by $23 \%$ strains in the framework of coagulase-negative staphylococci, and $75 \%$ of them were susceptible exclusively to K14 bacteriocin.

Typing by means of staphylococcal bacteriocins, S. aureus, S. intermedius, coagulase-negative staphylococci.

Staphylococcal bacteriocins, also called staphylococcins, have already been described and characterized in detail ( $\mathrm{T}$ a g g et al. 1976; Pulverer and Jeljaszewicz 1976; Brandis 1981; I vanov 1983; Skalka 1985). Their lethal effect is not observed merely in the framework of the genus Staphylococcus, some of them also affect corynebacteria ( $P$ ar ke r and $S i m$ mons 1959; Skalka et al. 1983 a,b) listeriae (Dajani et al. 1970; Jetten and Vogels 1972), streptococci and bacilli ( $D a j a n i$ and $W a n n a m a k e r$ 1973; J e t ten and $V o-$ ge ls 1973) and even some gramnegative species, as Neisseria 
gonorrhoeae (Mor r is et al. 1978) or Escherichia coli (K a de r et al. 1984). It is apparent from the reviews and from the recent studies about staphylococcins ( $\mathrm{m}$ a $\mathrm{rda}$ and $\mathrm{Obdrzz}$ b le $\mathrm{k}$. 1981 ; $B$ a l u se $\mathrm{k}$ and $H$ á je K 1985; $\mathrm{Sk}$ a l ka 1986) that the main effort is directed towards the discovery as many bacteriocin producing strains as possible what can be used in characterization of staphylococcal strain. Bacteriocin synthesis is a valuable character of some staphylococcal strains, though it is not always as important as in the case of the exfoliatin producing S. aureus strains ( $P$ arker and S i m mons 1959; Anthony et al. 1972; Rogolsky et al. 1974; War ren et al. 1974). On the other hand, studies on the possibility of typing Staphylococcus spp. on the basis of their sensitivity to bacteriocins are published rarely (I va nov 1970; P u l verer and Je ljaszewicz 1976). The purpose of the present study was to ascertain whether or not a possibility exists to type staphylococcal strains by means of staphylococcal bacteriocins.

\section{Materials and Methods}

Media

Oxoid brain heart infusion CM 225 , 0xoid brain heart infusion agar CM 375, and agar blood base No. 4 Imuna were used.

Bacterial strains

Bacteriocin producers

Four staphylococcal strains producing bacteriocins were used, namely S. aureus UTO002 (kindly provided by Dr. Rogolsky), S. intermedius $O P-42, S$. intermedius $O P-12$, and $S$. epidermidis K14. The last mentioned three strains were selected from our collection of bacteriocin producers and they are deposited in the Czechoslovak National Collection of Type Cultures as M 23/25, M 24/85 and $M 25 / 85$.

Basic indicator strains

Corynebacterium renale CCM 5740, Corynebacterium pseudodiphtheriticum CNCTC Psdi 5/78, S. aureus (Oxford 209P) CNCTC Mau 28/58 and S. aureus $\mathrm{CB}-27$, all previously described ( $\mathrm{k} k$ a lk a et al. 1983b; Skalka 1986), were used as basic indicator strains.

Staphylococcal strains under study

A total od 1314 staphylococcal strains was tested. The strains were classified according to our previous description ( $5 \mathrm{ka} \mathrm{ka}$ 1985). The set of 5 . aureus strains was composed of 111 biovar $A$ strains isolated from man, 34 biovar B strains isolated from poultry, 730 biovar C strains isolated from secrets of bovine mastitic udders, and 5 biovar D strains isolated from hares. Furthemore 224 S. intermedius strains and 210 coagulase-negative staphylococci were tested. The last mentioned strains were classified as $44 \mathrm{~S}$. epidermidis, $38 \mathrm{~S}$. haemolyticus, $35 \mathrm{~S}$. hominis, 23 S. simulans, 15 S. saprophyticus, 13 S. capitis, 9 S. xylosus, 6 S. cohnii, 6 S. warneri, 4 S. gallinarum, 2 S. caprae, and 15 strains. could not be alloted to any staphylococcal species.

Nature of bacteriocins of the producer strains

The producer strains were tested as on their activity on basic indicator strains, as on the mutual antagonistic action. Sen- 
sibility of bactericidal exosubstances to chloroform and trypsin (B r a ndis 1981) were also determined.

Bacteriocin sensibility assay

A modification of deferred method was employed in the following way. Spots of producer (active) strains were given in a diametric line on the surface of the agar medium and the plates were incubated at $37^{\circ} \mathrm{C}$ for $48 \mathrm{~h}$. Then the strains under investigation were inoculated on the plates. In order to obtain a close lawn, a drop of a $24 \mathrm{~h}$ broth culture was spread by means of an L-shaped wire in such a way that the edge of the lawn ran alongside of the spots of bacteriocin producers. After that a $24 \mathrm{~h}$ reincubation at $37{ }^{\circ} \mathrm{C}$ followed, then the results were evaluated. The result was considered positive, if there was a growth-inhibition zone of $2 \mathrm{~mm}$ and broader in the lawn of the investigated strain.

Results

Properties of antagonistic exosubstances of four testing strains are presented in Table l. Growth of the corynebacterial and staphylococcal strains used as indicators was inhibited by all active strains. Exosubstances of all active strains were found to be trypsin-sensitive. The bacteriocin UT0002 was inactivated by chloroform, while the bacteriocins OP-42, OP-12 and Kl 4 were chloroform-resistant.

Table 1

Properties of bacteriocins under study

\begin{tabular}{|c|c|c|c|c|}
\hline Producer strain & UT0002 & $\mathrm{OP}-42$ & OP-12 & $\mathrm{K} 14$ \\
\hline Staphylococcus & aureus & intermedius & intermedius & s epidermidis \\
\hline $\begin{aligned} \text { Relation to trypsin } \\
\text { chloroform }\end{aligned}$ & $\begin{array}{l}S \\
S\end{array}$ & $\begin{array}{l}\mathrm{S} \\
\mathrm{R}\end{array}$ & $\begin{array}{l}\mathrm{S} \\
\mathrm{R}\end{array}$ & $\begin{array}{l}\mathrm{S} \\
\mathrm{R}\end{array}$ \\
\hline $\begin{array}{l}\text { Mutual aniagonistic effect } \\
\text { on strains } \\
\qquad \begin{array}{ll}\text { !JTOOO2 } \\
\text { OP-42 } \\
\text { OP-12 } \\
\text { K14 }\end{array}\end{array}$ & $\begin{array}{l}- \\
- \\
-\end{array}$ & $\begin{array}{l}+ \\
- \\
- \\
-\end{array}$ & $\begin{array}{l}+ \\
- \\
- \\
-\end{array}$ & $\begin{array}{l}+ \\
+ \\
+ \\
-\end{array}$ \\
\hline $\begin{array}{l}\text { Effect on basic indicator set } \\
\text { C. renale } \\
\text { C. pseudodiphtheriticum } \\
\text { S. aureus OX } 209 \mathrm{P} \\
\text { S. aureus CB } 27\end{array}$ & $\begin{array}{l}+ \\
+ \\
+ \\
+\end{array}$ & $\begin{array}{l}+ \\
+ \\
+ \\
+\end{array}$ & $\begin{array}{l}+ \\
+ \\
+ \\
+\end{array}$ & $\begin{array}{l}+ \\
+ \\
+ \\
+\end{array}$ \\
\hline
\end{tabular}


Most of the tested staphylococcal strains were susceptible to the bacteriocin of the strain Kl4 which inhibited $99.31 \%$ strains S. aureus biovar C, 97.33 \% S. aureus biovars A, B, D, $91.96 \%$ S. intermedius, and $77.14 \%$ coagulase-negative staphylococci. The bacteriocin UTO002 acted on $99.45 \%$ S. aureus biovar C and $98.66 \%$ S. aureus biovars A, B, D, but on only $1.33 \% \mathrm{~S}$. intermedius. The coagulase-negative staphylococci were resistant to its action. Susceptibility towards the bacteriocin OP-12 was observed in $95.61 \% \mathrm{~S}$. aureus biovar C, and $61.16 \% \mathrm{~S}$. intermedius, but in no more than $7.33 \% \mathrm{~S}$. aureus biovars $\mathrm{A}, \mathrm{B}, \mathrm{D}$, and $1.9 \%$ coagulase-negative strains. In the case of the bacteriocin OP-42, susceptibility was observed in $94.79 \%$ S. aureus biovar C and $54.46 \%$ S. intermedius, but in only $6.66 \% \mathrm{~S}$. aureus biovars $A, B, D$, and in $1.9 \%$ coagulase-negative staphylococcal strains.

Table 2

Susceptibility patterns of investigated staphylococci

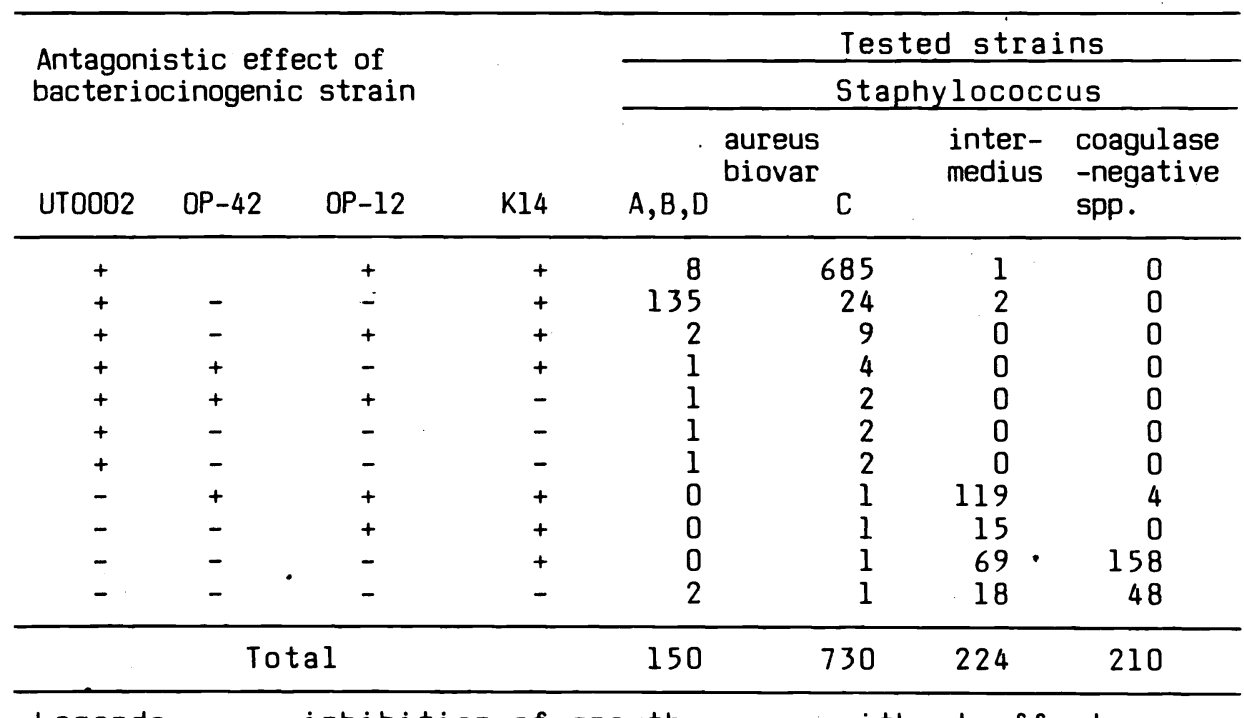

Legends: + = inhibition of growth $\quad-=$ without effect

From the point of view of their sensitivity to the bacteriocin used, the strains of $S$. aureus biovar $C$ fell into ten groups. The most numerous group was characterized by susceptibility to all four bacteriocins and comprised $93.83 \%$ strains of the biovar $C$. Susceptiblity to the bacteriocins UTO002 and K14, but resistance to those of the strains $O P-42$ and $O P-12$ were characteristic for $90 \%$ strains $S$. aureus biovars A, B, D. The largest group of S. intermedius comprised $53.12 \%$ strains resistant to the bacteriocin UTO002 but susceptible to the action of other three, while $30.8 \%$ strains of this species were susceptible to the bacte- 
riocin $\mathrm{Kl} 4$ and $8.03 \%$ S. intermedius strains were resistant to all four bacteriocins. Susceptibility patterns of coagulase-negative staphylococci were not related to species competence. The most numerous group of them comprised 75.23 \% strains. Resistance to all four bacteriocins was found in $22.85 \%$ coagulase-negative staphylococci. The remaining combinations of susceptibility applied only to a small number of the strains under study (Table $2)$. Typical results are presented on Figures 1 - 3 .

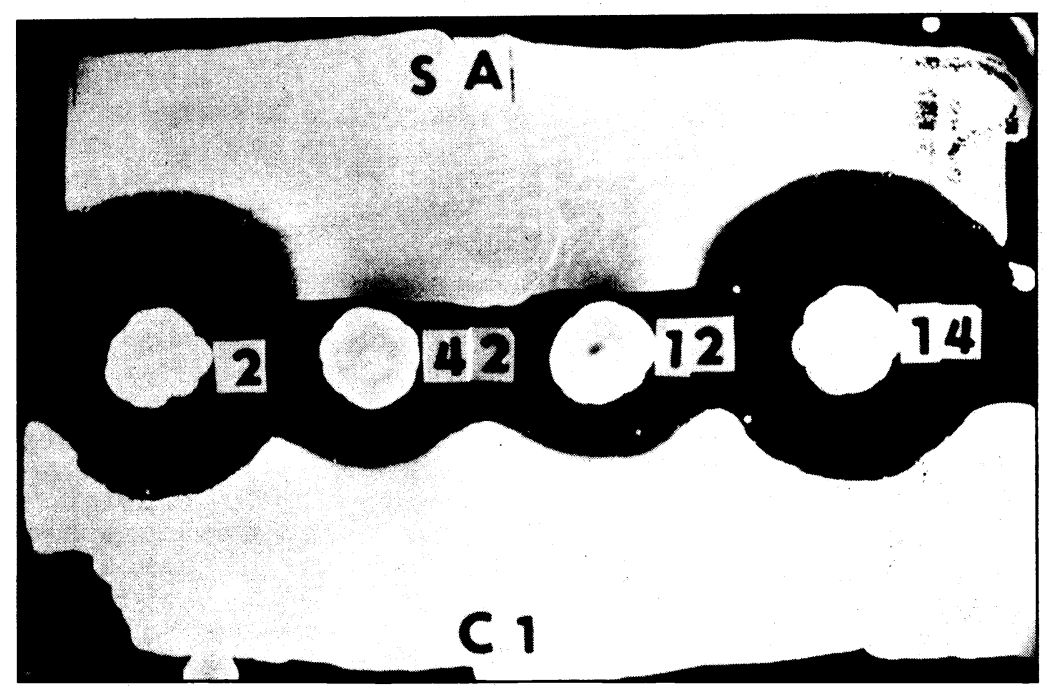

Fig. 1. Strains of $S$. aureus biovar $A(S A)$ and biovar $C\left(C_{1}\right)$ are tested against bacteriocin producers 5 . aureus UTO002 (2), S. intermedius OP-42 (42), S. intermedius OP-12 (12), and

S. epidermidis $\mathrm{K} 14$ (14)

Discussion

Following up our previous studies ( $5 \mathrm{k}$ a $1 \mathrm{ka}$ et al. 1983a, b; Ska lka 1985, 1986), we obtained a collection of bacteriocin producing staphylococci, from which we selected threg strains for the present work and we added the well known bacteriocin producer strain S. aureus UT0002 (R g o lsky et al. 1974; Warren et al. 1974) to obtain a set. The choice of producer strains was determined by our working hypothesis that strains optimal for bacteriocinotyping are not those with a broad effect, but rather with a differential one.

Bacteriocins are always described to be chloroform resistant. Their sensitivity to chloroform is only occasional ( $\mathrm{T}$ a g g et al. 1975), and chloroform-method ( $D$ a jan $i$ and $W$ a $n$ n a m a $\mathrm{r}$ 1973) is employed for search of new active strains (Ba l usek 


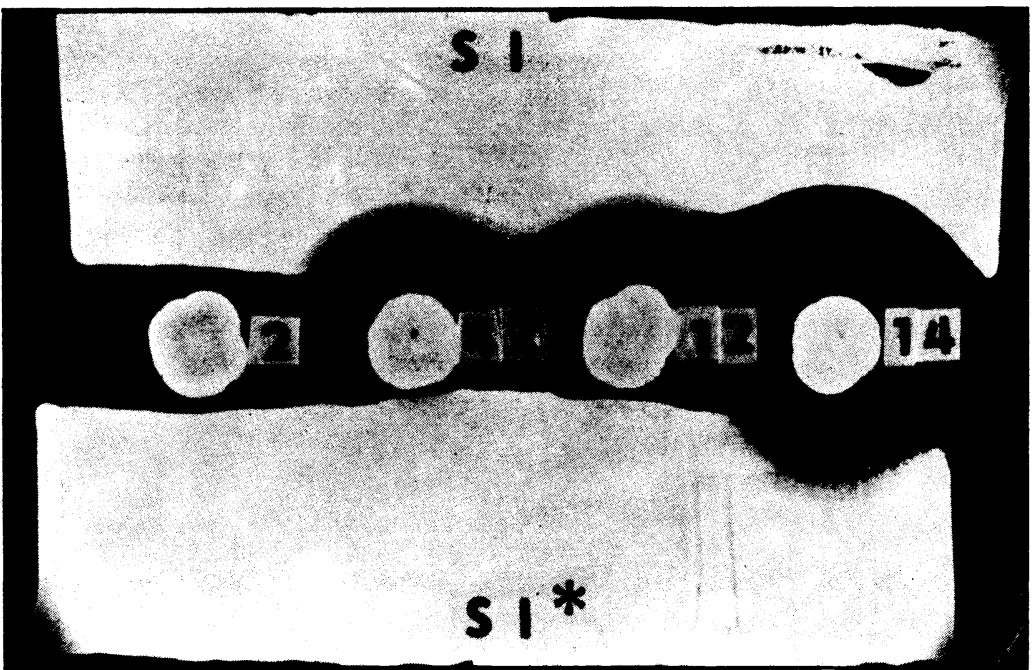

Fig. 2. Two strains of $S$. intermedius (SI, SI*) differently susceptible are tested against the same producers as on Figure 1

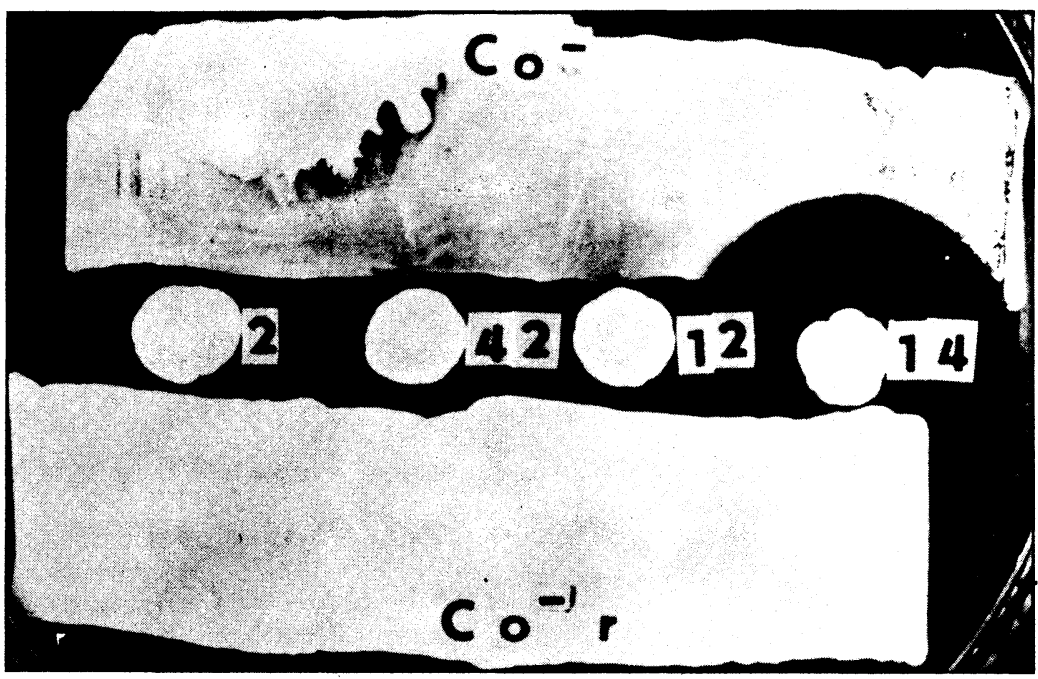

Fig. 3. Two strains of coagulase-negative staphylococci ( $\mathrm{Co}^{-}, \mathrm{Co}^{-} \mathrm{r}$ ) are tested against the same strains as on Figures 1 and 2 
and $H$ ájek 1985). Our observation about chloroform sensitivity of the exosubstance of UTOOO2 strain is surprising and it has not been described till now.

Our effort to use the bacteriocinotyping of staphylococci is not unique, but unlike previous studies (I va nov 1970; P u l$v e r e r$ and Jel jas z ewicz 1976), it considers as the existence of two coagulase-positive species as the biovars in the framework of $S$. aureus.

Larger sets of active strains, six and seven respectively, were used in comparable studies ( I v a n o 1970 ; P u l verer and $\mathrm{Jel} j \mathrm{j}$ s zewicz 1976), and six groups of sensitivity patterns were ascertained in one of them ( $I \vee$ a $n$ o 1970 ), whilst nine groups in the other ( $P$ u $l v e r e r$ and $J$ e l jas z e wi $z$ 1976). Nevertheless, only S. aureus strains were typed and the group susceptible to all active staphylococci comprised $96 \%$.

The use of the set of four active strains described in this. paper made it possible to differentiate the majority of 5 . aureus, S. intermedius and coagulase negative strains, further within these three groups of staphylococci several susceptibility types could be established. With the exception of the strains resistant to all four bacteriocins, $99.2 \%$ of the staphylococcal strains under study were sensitive to the Kl4 bacteriocin. The susceptibility to the bacteriocin UT0002 differentiated almost all $S$. aureus strains from those of $S$. intermedius and coagulase-negative ones. Bacteriocins of the $S$. intermedius strains OP-42 and OP-12 facilitated the formation of groups within the framework of $S$. aureus and $S$. intermedius, and they inh:bited growth of biovar C strains above all. The use of the bacteriocin Kl4 is turned to account of broad activity spectrum of this exosubstance.

Though further developments are likely, it is felt that the results obtained represent a contribution to the field of staphylococcal bacteriocins in general, and in particular to their practical use.

$\frac{\text { Typizace Staphylococcus aureus, Staphylococcus intermedius }}{\frac{\text { a koaguláza-negativnĺch stafylokokúpoužitím }}{\text { stafylokokových bakteriocinú }}}$

Senzitivita ke stafylokokovým bakteriocinưm byla zjištována u 1314 kmenú stafylokokú animální a humánní provenience, u kterých se neprokázala produkce bakteriocinủ. Jako producenti bakteriocinú se použily kmeny $S$. aureus UT0002, $S$. intermedius $O P-42, S$. intermedius $O P-12$ a $\mathrm{S}$. epidermidis Ki4. Soubor testovaných kmenú tvoŕilo 730 kmenú $S$. aureus biovar $C$, 111 kmenú 5 . aureus biovar $A, 34$ kmenú biovar $B, 5$ kmenú biovar $D$, dále 224 kmenú 5 . intermedius a 210 koaguláza-negativnich stafylokokú. Pro vyšetreni byla použita vlastni modifikace metody predkultivace producentú. Pro kmeny $S$. aureus biovar $C$ byla charakteristická citlivost $k$ bakteriocinủm vsech čty testačních kmenu, zahrnujici $94 \%$ kmenu této biovar. Pro kmeny $s$. aureus ostatnich biovar byla charakteristická senzitivita $k$ bakteriocinum kmenú UT0002 a Kl4 a současná necitlivost k bakteriocinủm kmenủ $O P-42$ a $O P-12$, pozorovaná u $90 \%$. V rámci druhu $S$. inter- 
medius bylo 53 \% kmenů citlivých $k$ substancím kmenů $0 \mathrm{P}-42,0 \mathrm{P}-12$ a Kl4, při současné necitlivosti k bakteriocinu kmene UT0002, 31 \% bylo citlivých jen k bakteriocinu Kl 4 a 8 \% kmenú bylo necitlivých ke všem bakteriocinům použitého testačního setu. Podobnou úplnou rezistenci mělo $23 \%$ kmenú koaguláza-negativních stafylokokủ, zatím co 75 \% bylo citlivých výlučně k bakteriocinu kmene Kl4. Odlišné kombinace senzitivity, než jaké byly uvedeny, pozorovaly jen u malých počtů vyšetrovaných stafylokoků.

Типизация Staphylococcus aureus, Staphylococcus
intermedius и коагулаза-отрицательных стафилококков
применением стафилококковых бактериоцинов

-. Проводились исследования чувствительности к стафилококковым бактериоцинам у 1314 штаммов стафилококков животного и человеческого происхождения, У которых не была установлена продукция бактериоцинов. В качестве продуцентов бактериоцинов были использованы птаммы $S$. aureus UTOOO2, S. intermedius OP-42, $S$. intermedius $\mathrm{OP}-12$ и $S$. epidermidis K14. В комплекс проверяемых штаммов входили 730 штаммов $S$. aureus biovar $C, 111$ штаммов $S$. aureus biovar A, 34 птамма biovar B, 5 штаммов biovar D, далее, 224 штамма $S$. intermedius и 210 коагулаза-отрицательных стафилококков. Для исследований был использован метод предварительной культивации продуцентов собственной модификации. Дла штаммов S. aureus biovar С была характерной чувствительность к бактериоцинам всех четырех проверяемых штаммов, включающих 948 штаммов данной биоварианты. Дла ттаммов $S$. aureus и остальных бисвариант была характерна́ чувствительность бактериоцидным штаммам UTOOO2 и K14 и одновременно нечувствительность к бактериоцинам штамм OP-42 и OP-12, наблюдаемая у 908. В рамках штамма S. intermedius 538 штаммов отличалось чувствительностью к веществам штаммов OP-42, OP-12 и К14 при одновременной нечувствительности $\mathrm{K}$ бактериоцину птамма UTOOO2, 318 отличался чувствительностью лишь к бактериоцину К14 и 88 штаммов - нечувствительностью ко всем бактериоцинам используемого набора. Аналогичной полной стойкостью отличались 238 штаммов коагулаза-отрицательных стафилококков, между тем как 758 - чувствительностью исключительно к бактериоцину штамма К14. Различные от приведенных комбинации чувствительности наблюдались лишь у небольшого числа исследуемых стафилококков.

References

ANTHONY, B. F. - GIULIANO, D. M. - OH, W.: Nursery outbreak of staphylococcal scalded skin syndrome. Rapid indentification of the epidemic bacterial strains. Am. J. Dis. Child., 124 , $1972,41-44$.

BALUSEK, J. - HÁJEK, V.: Antagonistic activities of coagulase positive staphylococci. J. Hyg. Epidemiol. Microbiol. Immunol. (Prague), 28, 1985: $147-154$.

BRANDIS, H.: Bacteriocins with special consideration of staphylococcins. Zbl. Bakt. Hyg. I. Abt., Suppl. 10, 1981, $719-729$. 
DAJANI, A. S. - GRAY, E. D. - WANNAMAKER, L. W.: Bactericidal substance from Staphylococcus aureus. Biological properties. J. Exp. Med., 131, 1970, 1004 - 1015 .

DAJANI, A. S. - WANNAMAKER, L. W.: In vitro and in vivo studies on a phage type 71 staphylococcal bacteriocin. p. $413-421$. In: JELJASZEWICZ, J.: Staphylococci and staphylococcal infections. S. Karger, Basel, 1973, $658 \mathrm{p}$.

IVANOV, N. A.: Staphylococcins, their properties, classification and use for typing of staphylococci. Bull. Exp. Biol. Med., $69,1970,559$ - 560 .

IVANOV, N. A.: Baktěriocinogenija stafilokokov. Žurnal Mikrobiol., Epidemiol. Immunol., No. 9, 1983: 3 - 7 .

JETTEN, A. M. - VOGELS, G. D.: Nature and properties of a Staphylococcus epidermidis bacteriocin. J. Bacteriol., 112, 1972: $243-250$.

JETTEN, A. M. - VOGELS, G. D.: Characterization and extrachromosomal control of bacteriocin production in Staphylococcus aureus. Antimicrob. Ag. Chemother., 4, 1973: 49 - 57.

KADER, A. O. - SAHL, H. G. - BRANDIS, $\vec{H}$.: Isolation and mode of action of a staphylococcin like substance active against gram-positive and gram-negative bacteria. J. Gen. Microbiol., 130, 1984: 2291 - 2300 .

MORRISS, M. D. - LAWSON, J. W. - ROGOLSKY, M.: Effect of a staphylococcin on Neisseria gonorrhoeae. Antimicrob. Ag. Chemother., 14, 1978 : $218-223$.

PARKER, M. T. - SIMMONS, L. E.: The inhibition of Corynebacterium diphtheriae and other gram-positive organisms by Staphylococcus aureus. J. Gen. Microbiol., 2l, 1959: 457 - 476 .

PULVERER, G. - JELJASZEWICZ, J.: Staphylococcal micrococcins. Zbl. Bakt. Hyg. I. Abt., Suppl. 5, 1976: 599 - 621.

ROGOLSKY, M. - WARREN, R. - WILEY, B. B. - NAKAMURA, H. T. - GLASGOW, L. A.: Nature of the genetik determinant controlling exfoliative toxin production in Staphylococcus aureus. J. Bacteriol., 117, 1974: 157 - 165.

SKALKA, B.: Ecology and cross-pathogenity of Staphylococcus aureus strains of diverse host origin (orig. in Czech). Research report. Brno, 1984.

SKALKA, B.: Staphylococcal bacteriocins - their present and future (orig. in Czech). Veterinářství, 35, 1985a: 316 - 317.

SKALKA, B.: An up to date scheme for the diagnostics of staphylccocci (orig. in Czech). Veter. Med. (Praha), 30, 1985b: $477-484$.

SKALKA, B.: Bacteriocin activity of Staphylococcus aureus, Staphylococcus intermedius and coagulase negative staphylococci. Acta vet. Brno, 55, 1986: 65-72.

SKALKA, B. - PILLICH, J. - POSPISIL, L.: New possibilities of staphylococcin detection in the exfoliatin producing strains of Staphylococcus aureus. Zbl. Bakt. Hyg. I. Abt. Orig. A 254 , $1983 a: 34-41$.

SKALKA, B. - PILLICH, J. - POSPISIL, L.: Further observations of Corynebacterium renale as an indicator organism in the detection of the exfoliatin positive strains of Staphylococcus aureus. Zbl. Bakt. Hyg. A 256, 1983b: $168-174$.

SMARDA, J. - OBDRŽ́LEK, V.: Staphylococcins: incidence and some characteristics of antibiotic action. Zbl. Bakt. Hyg. I. Abt., Suppl. 10, 1981: $407-411$. 
TAGG, J.R. - DAJANI, A. S. - WANNAMAKER, L. W.: Bacteriocins of gram positive bacteria. Bact. Rev., 40, 1976: 722 - 756. WARREN, R. - ROGOLSKY, M. - WILEY, B. B. -GLASGOW, L. A.: Effect of ethidium bromide on elimination of exfoliative toxin and bacteriocin production in Staphylococcus aureus. J. Bacteriol., 118, 1974 : $980-985$. 